\title{
Kimya Eğitiminde Düşünce Deneyleri Kullanılarak Lise Öğrencilerinin Argümantasyon Becerilerinin ve Eleştirel Düşünme Becerilerinin Geliştirilmesi ${ }^{1}$
}

\section{Ümmüye Nur Tüzün²}

Type/Tür:

Research/Araştırma

Received/Geliş Tarihi: April 13/

13 Nisan 2020

Accepted/Kabul Tarihi:

November 10/ 10 Kasim 2020

Page numbers/Sayfa No: 1290-

1314

Corresponding

Author/Illetişimden Sorumlu

Yazar: u_tuzun@hotmail.com

\section{$\checkmark$ iThenticate}

This paper was checked for plagiarism using iThenticate during the preview process and before publication. / Bu çalışma ön inceleme sürecinde ve yayımlanmadan önce iThenticate yazılımı ile taranmıştır.

Copyright $@ 2020$ by Cumhuriyet University, Faculty of Education. All rights reserved.

\section{Öz}

$\mathrm{Bu}$ çalışmanın amacı; kimya eğitiminde düşünce deneylerinin kullanıldığı argümantasyon temelli öğretimle lise öğrencilerinin eleştirel düşünme becerilerini geliştirmektir. Çalışmada, nitel araştırma desenlerinden eylem araştırması kullanılmıştır. Çalışmanın katılımcıları, Ankara ilinde bir ortaöğretim kurumunda öğrenim gören 33 dokuzuncu sınıf öğrencisidir. Veri toplama aracı olarak kamera kayıtları ve öğretim dizini çalışma yaprakları kullanılmıştır. Veri toplama süreci üç aşamalıdır. Birinci aşamada öğrenciler 12 adet özgün düşünce deneyini sosyal diyalektik bir bağlamda tartışmışlar; iddialarına veri, gerekçe ve destek sunmuşlar, iddia ve gerekçelerinin geçerli olmadığı durumlara dair çürütmeler yapılandırmışlar ve diğerlerinin iddialarına karşı iddialar sunmuşlardır. İkinci aşamada yine sosyal diyalektik bir bağlamda birinci aşamadaki düşünce deneylerinin kazanımlarına paralel biçimde özgün düşünce deneyleri üretmişlerdir. Son aşamada ise zihinsel diyalektik argümantasyonla birinci aşamadaki düşünce deneylerini argüman olarak yapılandırmışlardır. Veriler, içerik analiziyle çözümlenmiştir. Çalışma sonucunda; kimya eğitiminde düşünce deneylerinin kullanıldığı argümantasyon temelli öğretimle lise öğrencilerinin sosyal diyalektik argümantasyonla argümantasyon becerilerinin, zihinsel diyalektik argümantasyonla da düşünce deneylerini argüman olarak yapılandırma becerilerinin geliştirildiği tespit edilmiştir. Öğrencilerin sosyal diyalektik argümantasyon sırasında yapılandırdıkları düşünce deneyleriyle muhakeme gerektiren durum yapılandırma becerileri geliştirilmiştir. Öğrencilerin argümantasyon ve argüman becerilerini geliştirmek yoluyla da eleştirel düşünme becerileri geliştirilmiştir. İleriki araştırmalar için eleştirel düşünme becerilerinin gelişimine olanak veren farklı bağlamlar önerilerek tartışılmıştır.

Anahtar Kelimeler: Kimya düşünce deneyleri, argümantasyon, argüman, eleştirel düşünme, kimya eğitimi

\section{Suggested APA Citation/Önerilen APA Atıf Biçimi:}

Tüzün, Ü. N. (2020). Kimya eğitiminde düşünce deneyleri kullanılarak lise öğrencilerinin argümantasyon becerilerinin ve eleştirel düşünme becerilerinin geliştirilmesi. Cumhuriyet International Journal of Education, 9(4), 1290-1314. http:/ / dx.doi.org/10.30703/cije.719232

\footnotetext{
${ }^{1} \mathrm{Bu}$ çalışma yazarın doktora tez çalışmasından üretilmiştir.

2Dr. Öğretmen, Milli Eğitim Bakanlığı, Ankara/Türkiye

PhD., Ministry of National Education, Ankara/Turkey

e-mail: $\underline{\text { u_tuzun@hotmail.com ORCID ID: orcid.org/0000-0001-9114-0460 }}$
} 


\title{
Enhancing High School Students' Critical Thinking Skills and Argumentation Skills by Using Thought Experiments in Chemistry Education
}

\begin{abstract}
The aim of this study is to enhance high school students' critical thinking skills via enhancing their argumentation and argument skills in a thought experiments and argumentation-based chemistry teaching domain. In the study, as one of the qualitative research designs, action research was used. The participants of the study were 33 ninth grade students enrolled in a high school in Ankara province. As data collecting tools, camera records and teaching sequence worksheets were used. A three-step application process was carried on. First, the students argued 12 specific thought experiments in a social dialectic argumentation domain. They used data, warrants and backings for justifying their claims. They constructed rebuttals and counter claims. In the second step, the students constructed specific thought experiments using the first step's thought experiments' targets in a social dialectic argumentation domain. Finally, they reconstructed the first step's thought experiments as arguments in a logical dialectic argumentation process. Content analysis was utilized. It was found that the high school students' argumentation skills were enhanced via social dialectic argumentation and their reconstruction of thought experiments as argument skills were enhanced via logical dialectic argumentation in a thought experiments and argumentation-based chemistry teaching domain. Also students' skills in relation to forming a judgment case were enhanced via students' construction of thought experiments through social dialectic argumentation. In conclusion, students' critical thinking skills were enhanced via enhancing their argumentation and argument skills. For further studies, different domains for enhancing critical thinking skills were suggested.
\end{abstract}

Keywords: Chemistry thought experiments, argumentation, argument, critical thinking, chemistry education

\section{Giriş}

Her birey günlük yaşamını sürdürebilmek için çeşitli kararlar verir. Bireyin makul ve gerekçeli kararlar verebilmesi onun eleştirel düşünebilmesine bağlıdır. Eleştirel düşünme neye inanacağına ya da ne yapacağına karar vermeye odaklanan makul ve yansıtıcı bir düşünme tarzıdır (Norris ve Ennis, 1989'dan akt., West, 1994). Alanyazın günlük yaşamlarında karşılaştıkları problemlere makul çözümler üretebilen vatandaşlar yetiştirmek amacıyla fen öğretim programlarına eleştirel düşünmeyi entegre etmenin gerekliliğini savunmaktadır (Vieira, Tenreiro-Vieira ve Martins, 2011). Eleştirel düşünmeyi öğretmek için belirli bir yöntem olmamakla beraber öğrencilerin problemin doğasını anlamaları, problemin çözümünde olası alternatifleri düşünmeleri ve denemeleri için onlara fırsatlar sunulması izlenecek yollardan biridir (Bailin, 2002). Eleştirel düşünme becerileri argümantasyonun özellikle de sözel argümantasyonun içinde yer edinmiştir (West, 1994, s. iii).

Argümantasyon, iddiaları savunmak veya çürütmek için delillerin ve gerekçelerin sunulması sürecidir (Erduran ve Msimanga, 2014; Erduran ve Yan, 2009; Toulmin, 2003). Alanyazından argümantasyona dair daha geniş bir pedagojik felsefe ise yaklaşık kırk yıl öncesinden Schwab'ın bakış açısıyla sorgulayıcı araştırmayı sorgulayıcı araştırma; farklı bir bakış açısıyla da fen eğitiminde eleştirel düşünme eğitimi şeklindedir (Osborne, Erduran ve Simon, 2004). Bir argümanda iddialar, yani savunulan temel savlar, veriler üzerine yapılandırılır (Osborne, Erduran, Simon ve Monk, 2001). Bir argümanın içeriğine katkı sunan iddia, veri, gerekçeler ve desteklerin varlığ1 argüman anlamına gelirken, argümantasyon bu bileşenleri birleştirme süreci 
anlamına gelir (Simon, Erduran ve Osborne, 2006). Toulmin (2003, ss. 87-96), argümanı organizmaya benzetir. Bir argümanın hem yoğun bir anatomik yapısı, hem de psikolojik bir boyutu vardır. Dolayısıyla bir argüman detaylı bir biçimde ve açıkça yapılandırıldığında sayfalar sürebilir. Toulmin bir argümanı oluşturan bileşenleri; iddia, veri, gerekçe, sınırlayıcı, çürütme ve destek olarak tanımlamıştır. İddia; ortaya atılan savdır. Veri; iddiayı temellendiren durumlardır. Gerekçe; iddia ve veriyi ilişkilendiren ifadelerdir. Sınırlayıcl; gerekçenin etkisinde iddiayı veren verinin gücünün derecesine refere eden 'muhtemelen', 'büyük ihtimalle' gibi kelimelerdir. Çürütme; gerekçenin geçerliğinin bir tarafa konulduğu durumdur. Destek ise gerekçenin teminatıdır.

Alanyazında bir argüman retorik ya da diyalektik olarak yorumlanabilmektedir (Driver, Newton ve Osborne, 2000; Nussbaum ve Edwards, 2011). Driver, Newton ve Osborne (2000), retorik argümanı bir soruna neden ya da karşı-neden öneren ifadeler şeklinde tanımlamaktadır. Buna göre, bu şekildeki argümanlar genellikle başkalarını durumun savunulabilirliğine ikna etmek amacıyla kullanılır. Retorik argümanlar, fen derslerinde öğretmenin sınıfa bilimsel açıklama yaptığ durumlarda yaygın şekilde kullanılabilir. Diyalektik argüman yorumu ise; farklı bakış açıları olduğunda söz konusudur. Diyalektik argümantasyon sürecinde amaç, durumun akla yatkın savları üzerinde bir uzlaşmaya varmaktır. Diyalektik argümanlar bireysel ya da grup içerisinde yapılandırılabilir. Nussbaum ve Edwards'a (2011) göre, bireyin kendi kendine bilimsel tartışması zihinsel diyalektik argümantasyon olarak betimlenirken bireyin başkalarıyla bilimsel tartışması sosyal diyalektik argümantasyon olarak betimlenir. Bu süreçte argüman, argümana karşı argüman ve çürütmeyi temel alan çatı ise "zihinsel diyalektik şema" olarak adlandırılır.

Bilimde ve fen derslerinde, bir sonuç çıkarma aracı olarak düşünce deneyleri argümantasyonla entegre edilerek kullanılabilmektedir (Eyceyurt-Türk, Tüysüz ve Tüzün, 2018; Georgiou, 2005, s. 2). Düşünce deneyi hayali bir senaryoda tasvir edilen bir durumun gerçek olması halinde ne olacağı hakkında bir sonuca varmadır (Gendler, 1998). Bir düşünce deneyinde, bir bilgisizlik durumuyla ve bir soruyla başlanır, geçmiş deneyimler esas alınarak düşünülür ve yeni deneysel veri olmaksızın yeni bilgiye ulaşılır (Cooper, 2005). Düşünce deneyi, yanlış da olabilecek bir hipotezin sonuçlarını ortaya koyma sürecidir diyebiliriz (Recher, 1991). Reiner'e göre (1998) bir düşünce deneyi; varsayıma dayanan bir dünya, bir hipotez, zihinsel olarak gerçekleştirilen bir deney, geçmiş deneyimlere ve mantığa dayalı sonuçlar, bu sonuçlara dayalı kararlar gibi bileşenler içerir. Aslında iyi bir düşünce deneyi iyi bir argüman, kötü bir düşünce deneyi kötü bir argümandır (Norton, 1991). Düşünce deneyleri hayal ürünü gibi görünse de özellikle yirminci yüzyılın başında bilimsel tartışmalarla bilimin gelişmesine önemli katkılar sağlamıştır. Bilim tarihinden Einstein'ın foton tartısı düşünce deneyinin ortaya atılması ve çürütülmesi süreçleri bunun en güzel örneğidir. Einstein, Heisenberg'in belirsizlik ilkesini makul bulmuyordu. Belirsizlik ilkesini çürütecek bir düşünce deneyi yapılandırabilmek için çok uğraşmıştı. Bu süreçte, belirsizlik ilkesinin savunucusu Bohr ile defalarca karşı karşıya gelmişti.

1930'da Einstein, katıldığı bir kongre'de belirsizlik ilkesini çürütüyormuş gibi görünen bir düşünce deneyi önerdi. Bir yayın ucuna asıllp sarkıtılmış kapalı bir kutu kurgulamıştı. Kutunun yüksekliği yüksek duyarlıkla ölçülebiliyor, ağırlı̆̆ hesaplanabiliyordu. Kutunun içi, fotonlarla doluydu. Kutunun bir ucunda, tek bir fotonun kaçmasına izin verecek kadar küçük 
bir deliği kapatan duyarlı bir zamanlama düzeneği düşlemişti. Saat, belli bir anda kapağı ancak tek bir fotonun kaçmasına izin verecek hızda açıp kapayacaktı. Bu işlemin sonucunda kutunun yüksekliği değişsecek, böylece de kaçan fotonun enerjisi ve tam olarak hangi anda kaçtı̆̆ ölçülmüş olacaktı. Einstein'ın kendi formülü $E=m c^{2}$ buna olanak tanıyordu.

Düşünce deneyi görünüşte inandırncıydr. O gecenin Bohr'un en endişeli gecesi olduğu anlatılır. Ne var ki ertesi gün Bohr, Einstein'ı kendi görelilik kuramıyla çürütecekti.

Bohr, düzeneğin bir fotonun ağırlı̆̆ını ölçebilmesi için çok esnek ve olağanüstü uzunluğa sahip bir yaya asılmış olması gerektiğini açıkladı. Bohr'a göre, foton kaçtığı anda, kutu, görelilik kapsamında değerlendirilmesi gerekecek kadar hızh bir harekette bulunacaktı. Böyle bir hareket, kutunun foton'un haricinde kalan kütlesinin ve saatin doğruluğunu Einstein' ın kuramlarma göre tehlikeye sokacak ve kaçınılmaya çalışılan belirsizliği bizzat doğuracaktı. Einstein bu eleştiriyi kabullendi ve düzeneğindeki kusuru düzeltecek yeni bir modelleme bulamadı (abecem.net).

İlgili alanyazında, argümantasyon temelli fen öğretimi ile ilgili çok sayıda çalışma mevcuttur (Erduran, 2006; Erduran, Simon ve Osborne 2004; Osborne, Erduran, Simon ve Monk 2001; Osborne, Erduran ve Simon, 2004; Türk ve Kılıç, 2020). $\mathrm{Bu}$ çalışmalardan birinde, Erduran ve diğerleri (2019) araştırmalarında argümantasyon temelli fen eğitiminin yanı sıra fen eğitiminin farklı disiplinlerle ilişkilendirildiği argümantasyon uygulamalarının gerekliliğine vurgu yapmışlardır. Bir başka araştırmada fen sınıflarında argümantasyon kullanımının teoride gerekli görüldüğü durumun uygulamada pek yer edinememesinden yola çıkarak 25 fen öğretmen adayının argümantasyon çalıştayları sonundaki argümantasyon algıları araştırılmış ve çalışma sonucunda öğretmen adaylarının sınıflarında argümantasyon uygulamalarına dair pozitif algı geliştirdikleri bulunmuştur (Erduran, Kaya ve Çetin, 2016). Lazarou, Erduran ve Sutherlend (2017) benzer olarak iki sene süren deneysel araştırmalarında, öğretmenlerin argümantasyon algısının, araştırma projesinin etkinlikleri süresince nasıl farklılaştığını takip etmişler ve araştırma projesi süresince öğretmenlerin argümantasyon algilarının kronolojik evrimini de derinlemesine irdelemişlerdir. Simon, Erduran ve Osborne (2006), fen sinıflarında argümantasyon öğretimini öğretme üzerine yürüttükleri araştırmalarında 12 öğretmenle bir y1l boyunca materyal ve strateji üretmek amacıyla çalışmışlar ve öğretmenlerin argümanlarını Toulmin argüman modeli ile analiz etmişlerdir. Bu araştırmada, dersleri yüksek kalitede argümantasyon içeren öğretmenlerin öğretim süreçlerinin, öğrencileri argümantasyona daha iyi yönlendirebildiği görülmüştür. Argümantasyon temelli kimya öğretiminin kimya öğretmen adaylarının kavramsal değişimlerine etkisinin incelendiği başka bir araştırmada ise, öğretmen adaylarının akranlarıyla sosyal etkileşim içerisinde delillere dayalı argümanlar ve karşı argümanlar yapılandırmaları sağlanmış ve bu süreçte katılımcıların hem kendilerinin hem de diğerlerinin argümanlarını eleştirmelerinin teşvik edildiği bir öğretim ortamı oluşturulmuş ve bu argümantasyon sürecinin öğretmen adaylarında olumlu yönde kavramsal değişimi sağladığı gözlenmiştir (Köseoğlu, Tümay ve Akben, 2007). Argümantasyonun fen sınıflarındaki uygulamalarına bakıldığında ise bir araştırmada bütanın konformasyonel izomerlerinin öğretiminde argümantasyon aktivitesi kullanılmış; yüksek performans gösteren öğrenci gruplarının çoklu çürütmeler yapabildiği, düşük performans gösteren öğrenci gruplarının delilin güvenirliğini sorgulamada bile yetersiz kaldıkları araştırma sonucunda ortaya konulmuştur (Erduran ve Pabuccu, 2017). Erdoğan, Özbilgin ve Köseoğlu (2007) tarafından 
dokuzuncu sınıf öğrencilerine periyodik sistem konusunun öğretiminde argümantasyon yönteminin etkisi araştırılmış ve deney grubundaki öğrencilerin akademik başarılarının arttığı ve ayrıca öğrencilerin bilimi bilme yolları ile ilgili anlayışlarının geliştiği bulunmuştur. Lise öğrencilerine mol konusunun argümantasyon yöntemi ile öğretildiği bir deneysel araştırmada ise kavramsal değişim ve başarı açısından deney grubu öğrencilerinin daha iyi olduğu tespit edilmiştir (Özer, 2009). Benzer başka bir deneysel araştırmada ise ortaokul 8. sınıf öğrencilerine asit-baz konusu argümantasyon yöntemi ile öğretilmiş ve kavram öğretiminde, problem çözmede, bilimin doğası algısı ve bilimsel muhakeme edindirmede argümantasyonun geleneksel öğretimden avantajlı olduğu bulunmuştur (Tekeli, 2009). Alanyazındaki araştırmalar öğretmenlerin argümantasyonun pedagojik felsefesini uygulamalı öğrenmeleri ile öğrencilerin argümantasyon yaklaşımı temelinde öğretim sürecinde fen kavramlarını öğrenmeleri temaları etrafında toplanmıştır; bu çalışmada ise alanyazından farklı olarak öğrencilerin argümantasyon temelinde daha derinlemesine ve aşamalı öğretim süreçlerinde argümantasyon becerilerini geliştirmek amaçlanmıştır.

Öte yandan ilgili alanyazında, argümantasyon ile eleştirel düşünme becerileri arasındaki ilişkinin incelendiği araştırmalara örnek olarak; argümantasyonun eleştirel düşünme üzerine etkisini belirleme amaciyla 74 öğrenciyle ön test - son test kontrol gruplu olarak yürütülen bir araştırma sunulabilir. Araştırmada 90 dakikalık argümantasyon eğitiminin verildiği deney grubu lehine, 'veri yorumu' ve 'argüman' alt testlerinde istatistiksel olarak anlamlı bir fark bulunmuştur (West, 1994). Eleştirel düşünme soruları ve argüman yapılarını inceleyen başka bir araştırma ise 30 yedinci sınıf öğrencisiyle altı ay boyunca sosyobilimsel konularda ve fen konularında yürütülmüştür. Öğrenciler güncel olaylar hakkında yazmış ve tartışmışlardır. Deney grubu, başarılı bir biçimde eleştirel düşünme soruları yapılandırırken aynı zamanda argüman - karşı argüman entegrasyonunu içeren argümanlar da üretmişlerdir (Nussbaum ve Edwards, 2011). Alanyazındaki araştırmalar, argümantasyonun eleştirel düşünmenin gelişimini desteklediğini gösterirken bu çalışmada da alanyazından farklı olarak daha derinlemesine bir uygulama sürecinde sosyal diyalektik argümantasyonla, muhakeme gerektiren durumlar olarak düşünce deneyleri yapılandırmayla ve zihinsel diyalektik bir süreçte düşünce deneylerini argüman olarak yapılandırmayla öğrencilerin eleştirel düşünmeleri geliştirilmeye çalışılmıştır.

Fen alanı derslerinin öğretiminde düşünce deneyleri temelli araştırmalar da alanyazında önemli bir yere sahiptir. Reiner'in (1998) araştırmasında öğrenciler işbirlikli bir süreçte bilgisayarda optik bir simülasyon yapılandırmıştır. Optik simülasyon yapılandırma sürecinde öğrencilerin uygulamanın zihinlerinde yürüttükleri kısmı düşünce deneyi olarak değerlendirilmiştir. Düşünce deneyinin analizi varsayıma dayanan bir dünya, bir hipotez, zihinsel olarak gerçekleştirilen bir deney, geçmiş deneyimlere ve mantığa dayalı sonuçlar, bu sonuçlara dayalı karar bileşenleri üzerinden yapılmıştır. Araştırmada, düşünce deneyleri bilgisayar tabanlı yürütüldüğü takdirde işbirlikli öğrenme için etkili araçlar olarak kullanılabileceği belirtilmiştir. Gilbert ve Reiner (2000) araştırmalarında, fizik eğitiminde lisede 16-18 yaş grubuna ve üniversitede birinci sınıf öğrencilerine düşünce deneylerinin ne olduğu, nasıl yapılandırıldıkları ve öğrencilere uygulanan düşünce deneyinin onlarda 
nasıl bir kanı bıraktığı sorularına cevap verecek şekilde bir süreç yürütmüşlerdir. Süreç alanyazında düşünce deneylerinin pedagojik uygulamasının nasıl yer edindiğini görmek adına önemlidir. Lattery (2001), fizik sınıfından üç öğrenciye Galileo'nun düşünce deneyini uygulamıştır; bu süreçte öğrenciler arasında bir tartışma başlamıştır. Tartışma sırasında yeni düşünce deneyleri de önerilmiştir. Öğrenciler düşünce deneyinin çözümünde anlaştıkları sonucu laboratuvar ortamında test etmiş ve farklı bir sonuç bulmuşlardır. Projeyi takiben öğrencilerden bir makale yazmaları ve fakülteye bir sunum yapmaları istenmiştir. Çalışma sonunda, projenin öğrenciler için nitelikli bir öğrenme deneyimi sağladığı sonucuna varılmıştır. Farklı bir araştırmada ise hareket ile alakalı düşünce deneylerini öğrencilerin nasıl yorumladıklarına bakılmıştır. Araştırma sonucunda fizikte problem çözmede düşünce deneylerinin etkililiği vurgulanmıştır (Georgiou, 2005). Benzer olarak Bademci (2008) ve Dayı (2011) tarafından yürütülen araştırmalarda fizikte hareket ve basınç konularında lise ve üniversite öğrencilerinin bir problem çözme davranışı içinde tasarladıkları düşünce deneyleri ve bu düşünce deneylerinin yapıları incelenmiştir. Alanyazında sunulan düşünce deneyi temelli araştırmaların daha çok fizik alanında olduğu göz önünde bulundurularak bu çalışma alanyazında kimya alanında düşünce deneyi temelli uygulamalara pedagojik bir felsefe sunacak olması bakımından önemlidir. Ayrıca bu çalışmada alanyazındaki Lattery'nin (2001) araştırmasındaki öğrencilerin bir düşünce deneyinden yeni düşünce deneyleri önermeleri süreci de genişletilmiş; öğrenciler düşünce deneylerinden düşünce deneyleri üretmişlerdir.

$\mathrm{Bu}$ çalışmada eleştirel düşünme - argümantasyon - düşünce deneyleri üçlemesi birlikte ele alınmıştır. Çalışma alanyazına öğrencilerin sosyal diyalektik bir bağlamda kimya düşünce deneylerini nasıl argüme edeceklerine, bu düşünce deneylerinden yola çıkarak kendi düşünce deneylerini nasıl yapılandıracaklarına ve zihinsel diyalektik bir süreçte düşünce deneylerini argüman olarak nasıl yapılandıracaklarına dair derinlemesine ve çok aşamalı bir uygulama örneği sunacak olması bakımından önemlidir. Böylece çalışmanın yaygın etkisi; sürecin derinlemesine ve ayrıntılı betimlemesi sayesinde fen öğretim ortamlarını düşünce deneylerinin argümesi ile öğrencilerde eleştirel düşünme becerileri geliştirmek amacıyla yapılandıran eğitimcilere ve araştırmacılara rehber alınabilecek olması ile sağlanacaktır. Bu bağlamda araştırmanın sorusu: “Kimya eğitiminde lise öğrencilerinin düşünce deneyleri temelinde argümantasyon süreçlerinin ve argümanlarının kalitesinin geliştirilmesi suretiyle eleştirel düşünme becerileri nasıl geliştirilebilir?" biçiminde yapılandırılmıştır. Araştırmanın alt soruları da şu şekildedir:

- Öğrenciler düşünce deneylerini sosyal diyalektik bir süreçte argüme etmeleri nasıl sağlanabilir?

- Sosyal diyalektik argümantasyon sürecinin kalitesi nasıl belirlenebilir?

- Öğrencilerin düşünce deneylerden düşünce deneyleri yapılandırmaları suretiyle muhakeme gerektiren durum yapılandırma becerileri nasil geliştirilebilir?

- Öğrencilerin zihinsel diyalektik bir biçimde düşünce deneylerini argüman olarak yapılandırma becerileri nasıl geliştirilebilir? 


\section{Çalışmanın Amacı}

$\mathrm{Bu}$ çalışmanın amacı kimya eğitiminde düşünce deneylerinin kullanıldığı argümantasyon temelli öğretimle lise öğrencilerinin argümantasyonlarının ve argümanlarının kalitesini geliştirmek suretiyle onların eleştirel düşünme becerilerini geliştirmektir.

\section{Çalışmanın Deseni}

\section{Yöntem}

Bu çalışma nitel araştırma temelinde yürütülmüştür. Olayların doğal ortamda gerçekçi bir biçimde ortaya konmasına yönelik bir sürecin izlendiği araştırma nitel araştırma olarak tanımlanır (Yıldırım ve Şimşek, 2008, s. 39). Nitel araştırma desenlerinden eylem araştırması, bireyin öğrenmesini kolaylaştıran yöntemi sistematik bir biçimde araştırır. Buradaki amaç yöntemi geliştirerek öğrencinin daha kolay öğrenmesini sağlamaktır (Norton, 2009, s. 59). Mevcut çalışmada kimya eğitiminde düşünce deneylerinin kullanıldığı argümantasyon temelli öğretimle lise öğrencilerinin argümantasyonlarının ve argümanlarının kalitesinin geliştirilmesi sürecini sistematik bir biçimde araştırmak için eylem araştırması tasarımı kullanılmıştır.

Eylem araştırmasında önce bir başlangıç noktası belirlenir. Daha sonra araştırmanın üzerine temellendirildiği teoriler betimlenir. Ardından araştırma soruları tanımlanır. Veriler toplanıp analiz edilip sonuçlar raporlaştırılır. En sonunda ise tanımlanan eylemin daha sonraki uygulamalar için yaygınlaştırılması söz konusudur (Sagor, 2000). Bu araştırmanın başlangıç noktasını "kimya eğitiminde eleştirel düşünme - argümantasyon - düşünce deneyleri temelinde derinlemesine ve çok aşamalı bir uygulama süreciyle öğrencilerin argümantasyonlarının ve argümanlarının kalitesini geliştirmek suretiyle eleştirel düşünmelerini geliştirmek" oluşturmuştur. Araştırmanın üzerine temellendirildiği teoriler olarak eleştirel teori ve argümantasyon teorisi betimlenmiştir. Veri toplama sürecinin derinlemesine olması, verilerin analizi ve sonuçların raporlaştırılması süreçlerinde de ayrıntılı betimlemeler sağlanmasıyla eylemin daha sonraki uygulamalar için örnek bir uygulama rehberi olmasının hedeflenmesiyle de yaygınlaştırma amaçlanmıştır.

\section{Katılımcilar}

Çalışma, Ankara'da bir ortaöğretim kurumunda öğrenim gören 33 dokuzuncu sınıf öğrencisiyle kendi araştırmacı öğretmenleri rehberliğinde yürütülmüştür. Çalışmanın katılımcılarının gönüllü olmaları ve dokuzuncu sınıfta öğrenim görmeleri, katılımcıların belirlenmesindeki seçimli örnekleme kriterleridir. Burada vurgulanması gereken bir husus da bir sınıfın bütün öğrencilerinin gönüllü olmasıdır; sınıfta gönüllü olmayan öğrenci olması durumunda ise o öğrencilerle öğretim yapılacak fakat verileri sürece dâhil edilmeyecekti. Ayrıca katılımcılara istedikleri an araştırmadan ayrılabilme haklarının olduğu da anlatılmıştır. Böyle bir durumla karşılaşılsaydı yine o öğrencilerle öğretim yapılmaya devam edilecek fakat verileri sürece dâhil edilmeyecekti. Katılımcılardan 22'si kız, 11'i erkektir. Katılımcıların yaş ortalaması $15^{\prime}$ tir.

\section{Uygulama ve Veri Toplama Süreci}

Çalışmanın katılımcılarına uygulama süreci öncesinde "argümantasyon”, "argüman”, "düşünce deneyi", "eleştirel düşünme" "düşünce deneylerinin sonucu destekleyen 
nedenlerle ya da argümanlara karşı-argümanlar sunmayla sosyal diyalektik bir bağlamda nasıl tartışılacağı", "düşünce deneyi bileşenleri", "Toulmin argüman modeli bileşenleri" kavramları anlatılmıştır. Bunun için ek bir ders ayrılmıştır. Çünkü katılımcıların daha öncesinde eleştirel düşünme - argümantasyon - düşünce deneyleri üçlemesi temelinde öğrenme deneyimleri yoktur.

Çalışmanın veri toplama süreci üç aşamalı olarak yürütülmüştür. Birinci aşamada ortaöğretim kimya dersi öğretim programı kimyasal değişimler ve maddenin halleri konuları kazanımlarına (2018) paralel biçimde 12 adet düşünce deneyi sosyal diyalektik argümantasyonla; öğrencilerin kendilerinin ve diğerlerinin düşünme stratejilerini takip ettikleri bir süreçte bilimsel olarak tartışılmıştır. Öğrenciler iddialarına veri, gerekçe, destek sunmuşlar, gerekçelerinin geçerli olmadı ğ 1 durumları belirtmişler yani çürütme sunmuşlar, ayrıca birbirlerinin iddialarına karşı iddia, çürütme de sunmuşlardır. Süreç kamera ile kaydedilmiştir.

İkinci aşama, sosyal diyalektik argümantasyon sürecinde birinci aşamadaki kazanımlara paralel biçimde, Reiner' in (1998) düşünce deneyi bileşenleri esas alınarak, öğrencilerin yeni düşünce deneylerini yapılandırmalarının sağlandı̆̆ı süreçtir. Bu süreçte öğrencilerin muhakeme gerektiren durumlar yapılandırma becerilerinin geliştirilmesi hedeflenmiştir. Süreç kamera ile kaydedilmiştir.

Üçüncü yani son aşamada ise, öğrencilerin argüman yapılandırma becerilerini geliştirilmesine yönelik olarak onların birinci aşamadaki 12 düşünce deneyini zihinsel diyalektik argümantasyonla Toulmin (2003) argüman modeli bileşenlerine (iddia, veri, gerekçe, destek, çürütme) göre argüman olarak yeniden yapılandırmaları ve bunları öğretim dizininin çalışma kağıtlarına yazmaları sağlanmıştır.

Bu uygulama sürecinde, kimya eğitiminde düşünce deneylerinin kullanıldığ 1 argümantasyon temelli öğretimle lise öğrencilerinin argümantasyonlarının kalitesi sosyal diyalektik argümantasyonla; argümanlarının kalitesi ise zihinsel diyalektik argümantasyonla geliştirilmeye çalışılmıştır. Sosyal diyalektik argümantasyonda argümanlara karşı-argümanlar sunuldukça argümantasyonun kalitesi artmış; zihinsel diyalektik argümantasyonda da argümanın bileşenleri arttıkça argüman kalitesi artmıştır. Sosyal diyalektik argümantasyon sürecinde öğrencilerin "sonucu desteklemek için nedenler yapılandırma becerileri" ile " karşı-argüman yapılandırma becerileri” geliştirilmiş; özgün düşünce deneylerini yapılandırmaları sağlanarak "muhakeme gerektiren durumlar yapılandırma becerileri" geliştirilmiş; argüman kalitesinin geliştirilmesi suretiyle de "argüman yapılandırma becerileri" geliştirilmeye çalışılmıştır. Öğrencilerin "sonucu desteklemek için nedenler yapılandırma becerisi", "karşı-argüman yapılandırma becerisi", "muhakeme gerektiren durumlar yapılandırma becerisi" ve "argüman yapılandırma becerisi" gelişimi de alanyazın temelinde onların eleştirel düşünme becerilerinin geliştiğinin göstergesidir (Cambridge Thinking Skills Syllabus, 2020-2022). Burada çalışmada her bir eleştirel düşünme becerisinin ne anlama geldiğini netleştirmekte de fayda vardır:

- Sonucu desteklemek için nedenler yapılandırma becerisi: Öğrencilerin sosyal-diyalektik argümantasyon bağlamında iddialarına, veri /gerekçe/destek sunabilmeleridir.

- Karş1-argüman yapılandırma becerisi: Öğrencilerin bir iddia ve gerekçelerine karşı-iddia ve gerekçeler sunabilmeleridir. 
- Muhakeme gerektiren durumlar yapılandırma becerisi: Öğrencilerin varsayıma dayanan bir dünya, bir hipotez, zihinsel olarak gerçekleştirilen bir deney, geçmiş deneyimlere ve mantığa dayalı sonuçlar, bu sonuçlara dayalı karar bileşenleri temelinde düşünce deneyleri yapılandirabilmeleridir.

- Argüman yapılandırma becerisi: Zihinsel diyalektik bir süreçte öğrencilerin düşünce deneylerini iddia, veri, gerekçe, destek ve çürütme bileşenleri temelinde argüman olarak yeniden kurgulayabilmeleridir.

\section{Veri Toplama Araçları}

Sosyal diyalektik argümantasyon sürecindeki veriler için kamera kayıtları kullanılmıştır. Zihinsel diyalektik argümantasyon süreci için ise ortaöğretim kimya dersi öğretim programı kimyasal değişimler ve maddenin halleri konuları kazanımlarına (2018) paralel biçimde yapılandırılan 12 adet düşünce deneyini öğrencilerin argüman olarak yeniden kurguladıkları öğretim dizinlerini içeren çalışma yaprakları kullanılmıştır.

Veri toplama araçlarının geçerliği araştırmacının da içlerinde yer aldığı alan eğitiminde uzman üç fen eğitimcisi tarafından kapsam geçerliği bakımından kontrol edilerek, güvenirliği ise aynı üç fen eğitimcisinin verileri kodlama ve ketegorilere yerleştirmeleri arasındaki uyum ile sağlanmıştır. Uyum; (aynı kodlar / bütün kodlar) x 100 ile hesaplanmıştır. Aritmetik ortalama alınarak hesaplanan ortalama uyum \%95'tir. Farklı yapılan kodlamalar üzerinde yeniden düşünülerek bir anlaşmaya varılmış; güvenirlik sağlanmıştır.

\section{Verilerin Çözümlenmesi}

Çalışmanın verileri içerik analiziyle çözümlenmiştir. Çalışmanın birinci aşamasında yani sosyal diyalektik argümantasyon sırasında çekilen kamera kayıtları önce yazılı metinlere dönüştürülmüştür. Daha sonra da elde edilen veriler alanyazında argümantasyon kalitesini belirlemek amacıyla tanımlanan seviyeler temelinde çözümlenmiştir (Erduran, Simon ve Osborne, 2004; Osborne, Erduran ve Simon, 2004).

Buna göre yalnız iddia kodu içeren argümanlar seviye 1 kategorisi, iddianın yanı sıra veri / gerekçe / destek kodu içeren argümanlar seviye 2 kategorisi olarak çözümlenmiştir. Seviye 2 kategorisine ait kodların yanı sıra zayıf çürütme kodu içeren argümanlar seviye 3 kategorisi, seviye 2 kategorisine ait kodların yanı sıra çürütme kodu içeren argümanlar seviye 4 kategorisi ve seviye 2 kategorisine ait kodların yanı sıra birden fazla çürütme kodu içeren argümanlar seviye 5 kategorisi olarak çözümlenmiştir (Erduran, Simon ve Osborne, 2004; Osborne, Erduran ve Simon, 2004).

Verilerin çözümlenmesi sürecinin örneklendirilmesi için "yaşamın olmadığ1 gezegende atmosfer bileşimini değiştirmekle uğraşan bilim insanları aynı sıcaklık, basınç ve mol sayıda $\mathrm{O}_{2}$ gazı içeren kapsülle $\mathrm{N}_{2}$ gazı içeren bir başka kapsülün aynı anda atmosfer girişinde patlamalarını sağlasaydı" ne olacağını yorumlayan öğrencilerin argümanlarının nasıl kodlandığı ve seviyeler temelinde kategorilendiği aşağıda sunulmuştur:

Ö4 kodlu öğrencinin argümanı: Azotun difüzyon hızı daha yüksektir (iddia) (seviye 1).

Ö1 kodlu öğrencinin argümanı: Oksijenin molekül kütlesi daha büyük olduğundan (veri), difüzyonu daha yavaştır (iddia) (seviye 2)... 
...Ö17 kodlu öğrencinin argümanı: Ĕ̆ger bilim insanları atmosferin bileşimini değiştirebilecek bilimsel bilgi ve teknolojik donanıma sahip olmasalardi; bu durumda gazların difüzyon hızın konuşuyor olmazdık (çürütme) (seviye 4).

Çalışmanın ikinci aşamasındaki sosyal diyalektik argümantasyon sürecinde öğrencilerin muhakeme gerektiren durumlar yapılandırma sürecinde özgün olarak yapılandırdıkları düşünce deneyleri öncelikle kamera kayıtlarından yazılı metinlere dönüştürülmüştür. Daha sonra elde edilen veriler; düşünce deneyinin bilimsel olarak doğru olması ve ortaöğretim kimya dersi öğretim programı kimyasal değişimler ve maddenin halleri konuları kazanımlarını (2018) içermeleri bakımından kontrol edilmiştir. Ön şartların sağlanması koşuluyla daha sonra düşünce deneyleri Reiner'in (1998) düşünce deneyi bileşenleri (varsayıma dayanan bir dünya, bir hipotez, zihinsel olarak gerçekleştirilen bir deney, geçmiş deneyimlere ve mantığa dayalı sonuçlar, bu sonuçlara dayalı karar) temelinde çözümlenmiştir. Çözümlemenin nasıl yapıldığına dair bir örnek aşağıda sunulmuştur:

İlginç Göl Düşünce Deneyi

Uzayda yeni, küçük bir gezegenin keşfedildiğini, bu gezegende de bir gölün olduğunu ve gölün de dünyada bulunmayan bir sıvıdan oluştuğunu varsayını (varsayıma dayanan bir dünya). Bilim insanlarn incelemek için bu gölün sıvısından bir numune almışlardır. (Örtük hipotez: gölün sivisından alınan numune mevcut enstrümantal yöntemlerle incelendiğinde bileşimi bulunabilir.) Bir çeşit bileşikten oluşan ve XYZ olarak formülize edilen bu siou ısıtıllnca sıvı ile gaz arası bir forma geçmiştir (geçmiş deneyimlere dayalı karşılaştırmalı olarak elde edilen sonuçlar). Buna göre $X Y Z^{\prime}$ nin sıvı, ara hal ve gaz fazları için hal değişim grafiğini yorumlayını (bu sonuçlara dayalı bir karar). (Zihinsel olarak gerçekleştirilen bir deney ise bütün süreçtir.)

Çalışmanın son aşamasında öğrencilerin birinci aşamadaki düşünce deneylerini zihinsel diyalektik argümantasyonla argüman olarak yeniden yapılandırmalarıyla çalışma yapraklarından edinilen öğrenci argümanları bilimsel olarak doğru olup olmamaları bakımından kontrol edilmiştir. Daha sonra da Toulmin (2003) argüman modeli bileşenleri (iddia, veri, gerekçe, destek, çürütme) temelinde kodlamalar yapılmış, argümanların içerdiği kodlara göre de kategoriler oluşturulmuştur. Örneğin iddia, veri, gerekçe kodlarını içeren bir argüman IVG (iddia-veri-gerekçe) kategorisi olarak yapılandırılmıştır.

\section{Bulgular}

Bu çalışmanın verilerinin çözümlenmesiyle edinilen bulgular

- Sosyal diyalektik argümantasyonun kalitesinin belirlenmesi, öğrencilerin sonucu desteklemek için nedenler yapılandırma ve karşı-argümanlar yapılandirma becerileri,

- Öğrencilerin muhakeme gerektiren durum, düşünce deneyi yapılandırma becerileri,

- Öğrencilerin argüman yapılandırma, düşünce deneyini argüman olarak yeniden kurgulama becerileri

başliklarıyla sunulmuştur.

1. Sosyal Diyalektik Argümantasyonun Kalitesinin Belirlenmesi, Öğrencilerin Sonucu Desteklemek için Nedenler Yapılandırma ve Karş1-Argümanlar Yapılandırma Becerileri 
12 düşünce deneyi (bknz. bulgular 3. bölüm) ikişerli gruplanarak her biri 15' er dakika süren altı sosyal diyalektik argümantasyon sürecinde tartışılmıştır. Öğrenciler sonuçlarını desteklemek için nedenler yapılandırmış; iddialarına veri, gerekçe, destek sunmuşlar, iddia ve gerekçelerinin geçerli olmadığı durumlar için çürütmeler yapılandırmış; birbirlerinin argümanlarına karşı-argümanlar sunmuşlardır. Kamera kayıtları yazılı metinlere dönüştürüldükten sonra alanyazında argümantasyon kalitesini belirlemek amacıyla tanımlanan seviyeler temelinde çözümlenmiştir. Elde edilen bulgular Tablo 1'de sunulmuştur.

Tablo 1.

Sosyal Diyalektik Argümantasyonun Kalitesinin Belirlenmesi*

\begin{tabular}{ccccccc}
\hline Düsünce & \multicolumn{7}{c}{ Sosyal diyalektik argümantasyonun kalitesi f } \\
Deneyi & S1 & S2 & S3 & S4 & S5 & Toplam \\
$1-2$ & 5 & 15 & 2 & 10 & 1 & 33 \\
$3-4$ & 7 & 15 & 3 & 18 & 1 & 44 \\
$5-6$ & 11 & 18 & - & 15 & 4 & 48 \\
$7-8$ & - & 17 & - & 8 & 4 & 29 \\
$9-10$ & 2 & 12 & - & 8 & - & 22 \\
$11-12$ & 2 & 11 & - & 15 & 2 & 30 \\
\hline
\end{tabular}

* Tablo 1'de S harfi seviyenin, fharfi frekansin kısaltmasıdır.

Tablo 1'de iddia kodu içeren öğrenci argümanları seviye 1 kategorisine, iddianın yanı sıra veri ya da gerekçe ya da çürütme kodları içeren öğrenci argümanları seviye 2 kategorisine alınmıştır. Seviye 2 kategorisine ait kodların yanı sıra zayıf çürütme kodu içeren öğrenci argümanları seviye 3 kategorisine, seviye 2 kategorisine ait kodların yanı sıra çürütme kodu içeren öğrenci argümanları seviye 4 kategorisine, seviye 2 kategorisine ait kodların yanı sıra birden fazla çürütme kodu içeren öğrenci argümanları seviye 5 kategorisine alınmıştır.

Tablo 1 incelendiğinde seviye 2 frekansları (f:15,15,18,17,12,11) ile seviye 4 frekanslarının (f:10,18,15,8,8,15) yakın olduğu görülmektedir. Buradan sosyal diyalektik argümantasyon sürecinde öğrencilerin düşünce deneyleri için iddia, veri, gerekçe ya da destek sunma becerilerinin yanı sıra iddiaya, gerekçeye ve birbirlerine çürütücü sunma becerilerinin de yüksek olduğu söylenebilir. Dolayısıyla düşünce deneylerinin kullanıldığı argümantasyon temelli kimya öğretimi sürecinde sosyal diyalektik argüman kalitesinin yüksek olduğu söylenebilir. Ayrıca seviye 2 frekanslarının yüksek olmasından öğrencilerin süreçte sonucu desteklemek için nedenler yapılandırma becerilerinin geliştiği; seviye 4 frekanslarının yüksek olmasından da öğrencilerin karşı-argüman yapılandırma becerilerinin geliştiği söylenebilir.

Tablo 1'de sunulan bulguların güçlendirilmesi amacıyla sözel argümantasyon sürecinden bir alıntı aşağıda sunulmuştur:

Düşünce Deneyi: Sülfür Bakterileri

Bir yerleşim birimine yakın mesafedeki bir bataklıkta sülfür bakterilerinin ürettiğinden üç kat daha fazla metan gazı üreten mutasyona uğramış yeni sülfür bakteri türlerinin bulunduğunu varsayiniz.

Mutasyona uğrayan bu bakteri türü yerleşim biriminde zehirlenmelerin başlamasının ardından keşfedilmiştir. 
Metan gazının oksijenli solunum yapan canlılar için atmosfer kirletici olarak davrandığını göz önüne alarak; metan gazının, atmosferdeki gaz karışımındaki yüzdesini nasıl azaltırsınız?

Ö10: Ö1 bitkiler ölüyor dedi (veri). Ö4 de yeşilliği çoğaltabiliriz dedi (iddia). Yeşilliği çoğaltırsak bitkileri olumsuz etkileriz (çürütme). İnsan hayatı yine olumsuz etkilenir (iddiaya karşı iddia) (çürütme) (seviye 4).

Ö14: Ĕğer bitki örtüsünü çok çoğaltırsam bir kısmı ölse bile bir kısmı yeşillik kalır (karşı iddiaya karşı iddia) (çürütme) (seviye 4).

Ö10: Yeşillik kalması önemli değil yine insanlar negatif etkilenecek (karşı iddiaya karşı iddiaya karşı iddia) (çürütme) (seviye 4).

Ö17 farklı bir çözüme yöneliyor: Bakteriler mutasyona uğradı (veri), çok metan gazı çıktı (veri), bu bakterileri azaltmam lazım (gerekçe), dolayısıyla bu bakterileri azaltacak yeni bir tür üretmem lazım (iddia) (seviye 2).

Ö8: Ö17'ye katılıyorum (iddia) (seviye 1).

Ö25: Ö17'ye katılıyorum (iddia) (seviye 1).

Ö4: Sülfür bakterilerinin mutasyona uğrama koşullarını ortadan kaldırabiliriz (iddia) (seviye 1) ..............

\section{2. Öğrencilerin Muhakeme Gerektiren Durum, Düşünce Deneyi Yapılandırma Becerileri}

Öğrenciler kamera kaydına alınan sosyal diyalektik argümantasyon sırasında birinci aşamadaki düşünce deneylerinin kazanımlara paralel biçimde, işbirlikli bir süreçte, Reiner'in (1998) düşünce deneyi bileşenlerini temelinde altı adet yeni düşünce deneyi yapılandırmışlardır. Burada düşünce deneyi, muhakeme gerektiren durum olarak alınmıştır. Düşünce deneyleri yaplandırılırken öğrenciler işbirlikli bir süreçte birbirlerinin düşünmelerini takip ederek düşünce deneyine katkılar sunmuşlardır. Sosyal diyalektik argümantasyonun kamera kayıtları, araştırmacı rehber öğretmen tarafından daha sağlıklı bir analiz için yazılı metinlere dönüştürülmüş, daha sonra da düşünce deneylerinin bilimsel olarak doğru olmaları ve ortaöğretim kimya öğretim programı kimyasal değişimler ve maddenin halleri kazanımları (2018) ile örtüşmeleri kontrol edilmiştir. Elde edilen bulgular Tablo 2' de verilmiştir.

Tablo 2.

Öğrencilerin Yapılandırdı̆̆ı Düşünce Deneylerinin Örtüştüğ̈̈ Ortaöğretim Kimya Programı Kimyasal Değişimler ve Maddenin Halleri Kazanımları Numaralar

\section{Düşünce}

Deneyleri

1.Yeni Tuz Kristali

Uzayda bir gezegende çok miktarda yeni bir tuz kristalinin keşfedildiğini varsayınız.

Bilim insanları bu tuz kristalini araştırıyorlar ve bu tuz kristalinin bileşiğinin içerdiği

iyonların dünyada var olmadı̆̆ını buluyorlar.

Sizce bu tuz kristali nasıl oluşmuştur?

2.Uzayan Canlı

Bilim insanlarının yeni bir gezegende solucana benzer yeni bir canlı türü keşfettiğini varsayınız.

Bu canlı türü incelenirken canlının çekildikçe uzadığı, uzadıktan sonra da eski haline dönmediği bulunmuştur. Bu durumun sebebi ne olabilir?

3.Renk Değiştiren Canlılar
Öğretim

Programı

Kazanım

No

9.3.5.1

9.4.2.1

9.4.1.1 


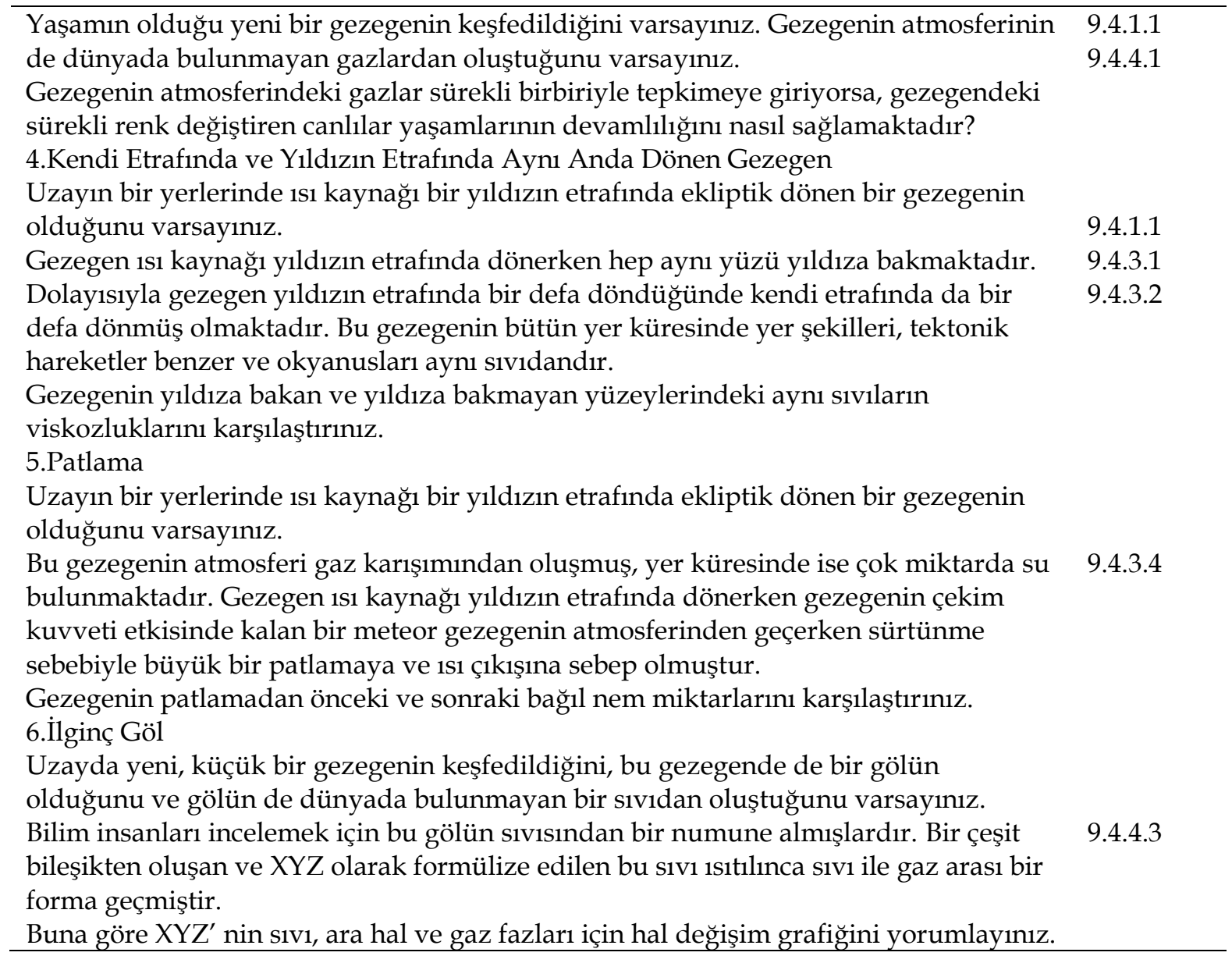

Tablo 2'de görüldüğgü üzere düşünce deneylerinden öğrencilerin yapılandırdıkları düşünce deneyleri dokuzuncu sınıf öğretim programı kazanımlarıyla örtüşmektedir.

Öğrencilerin yapılandırdıkları düşünce deneyleri en sonunda da Reiner'in (1998) düşünce deneyi bileşenleri temelinde kodlanmıştır. Elde edilen bulgular Tablo 3 'te sunulmuştur.

Tablo 3.

Öğrencilerin Yaplandırdıkları Düşünce Deneylerinin Reiner'in (1998) Düşünce Deneyi Bileşenlerine Uygunluğu Kontrolü

\begin{tabular}{cccccc}
\hline & \multicolumn{5}{c}{ Reiner'in (1998) Düşünce Deneyi Bileşenleri } \\
\cline { 2 - 6 } $\begin{array}{c}\text { Düşünce } \\
\text { Deneyi }\end{array}$ & $\begin{array}{c}\text { Varsayıma } \\
\text { Dayanan Bir } \\
\text { Dünya }\end{array}$ & Bir Hipotez & $\begin{array}{c}\text { Zihinsel Olarak } \\
\text { Gerçekleştirilen } \\
\text { Bir Deney }\end{array}$ & $\begin{array}{c}\text { Geçmiş } \\
\text { Deneyimlere } \\
\text { ve Mantı̆g } \\
\text { Dayalı Sonuç } \\
\text { Ç1karma }\end{array}$ & $\begin{array}{c}\text { Bu Sonuçlara } \\
\text { Dayalı } \\
\text { Karar Verme }\end{array}$ \\
1 & + & + & + & + & + \\
2 & + & + & + & + & + \\
3 & + & + & + & + & + \\
4 & + & + & + & + & + \\
5 & + & + & + & + & + \\
6 & + & + & + & + & + \\
\hline
\end{tabular}


Tablo 3 incelendiğinde ise düşünce deneylerinden öğrencilerin yapılandırdıkları düşünce deneylerinin Reiner'in (1998) düşünce deneyi bileşenlerini; varsayıma dayanan bir dünya, bir hipotez, zihinsel olarak gerçekleştirilen bir deney, geçmiş deneyimlere ve mantığa dayalı sonuç çıkarma, bu sonuçlara dayalı karar verme; içermesinden dolayı öğrencilerin düşünce deneyi yapılandırmada başarılı oldukları; bu sayede muhakeme gerektiren durum yapılandırma becerilerinin geliştiği söylenebilir.

\section{3. Öğrencilerin Argüman Yapılandırma, Düşünce Deneyini Argüman Olarak Yeniden Kurgulama Becerileri}

Öğrenciler zihinsel diyalektik argümantasyonla birinci aşamadaki her bir düşünce deneyini argüman olarak yeniden yapılandırmışlar, öğretim dizini çalışma yapraklarından elde edilen verilerle Toulmin (2003) argüman modeli bileşenleri (iddia, veri, gerekçe, destek, çürütme) kod olarak alınarak kategoriler oluşturulmuş ve frekanslar hesaplanmıştır. Toulmin argüman modelindeki 'sınırlayıcı' bileşeni kodlama sürecine dahil edilmemiştir. Elde edilen bulgular Tablo 4'te sunulmuştur.

Tablo 4.

Öğrencilerin Argüman Yapılandırma Becerileri*

\begin{tabular}{|c|c|c|c|c|c|c|c|c|c|c|}
\hline & \multicolumn{10}{|c|}{ Kategoriler ve $\mathrm{f}$} \\
\hline & $\dot{\mathrm{I}}$ & $\dot{\mathrm{I}}$ & $\dot{\mathrm{I}}$ & $\dot{\mathrm{I}}$ & $\dot{\mathrm{I}}$ & $\dot{\mathrm{I}}$ & $\dot{\mathrm{I}}$ & $\dot{\mathrm{I}}$ & $\dot{\mathrm{I}}$ & $\dot{\mathrm{I}}$ \\
\hline & $\mathrm{V}$ & V & $\mathrm{V}$ & $\mathrm{V}$ & V & $\mathrm{V}$ & V & V & V & $\mathrm{V}$ \\
\hline & G & $\mathrm{D}$ & G & G & G & G & G & G & G & G \\
\hline & Ç & Ç & $\mathrm{D}$ & Ç & $\mathrm{D}$ & $\mathrm{D}$ & D & $\mathrm{D}$ & $\mathrm{D}$ & $\mathrm{D}$ \\
\hline & & & & Ç & Ç & Ç & Ç & Ç & Ç & Ç \\
\hline & & & & & & Ç & Ç & Ç & Ç & Ç \\
\hline & & & & & & & Ç & Ç & Ç & Ç \\
\hline Düşünce & & & & & & & & Ç & Ç & Ç \\
\hline Deneyi & & & & & & & & & & Ç \\
\hline 1 & & & 1 & & 31 & 1 & & & & \\
\hline 2 & & & 3 & & 24 & 5 & 1 & & & \\
\hline 3 & 1 & & 1 & & 27 & 3 & 1 & & & \\
\hline 4 & & & 3 & & 15 & 13 & 2 & & & \\
\hline 5 & & 1 & & & 22 & 8 & 2 & & & \\
\hline 6 & & 1 & & & 18 & 14 & & & & \\
\hline 7 & & 2 & & & 9 & 17 & 5 & & & \\
\hline 8 & & & & & 18 & 13 & 2 & & & \\
\hline 9 & & & 2 & & 11 & 19 & 1 & & & \\
\hline 10 & & & & 1 & 10 & 7 & 10 & 4 & 1 & \\
\hline 11 & & & & & 11 & 17 & 2 & 2 & & 1 \\
\hline 12 & & & & & 14 & 10 & 8 & & 1 & \\
\hline
\end{tabular}

* Tablo 4'te iddia I, veri $V$, gerekçe $G$, destek $D$, çürütme Ç ve frekans fharfleriyle gösterilmiştir.

Tablo 4'ün yorumlanmasında Toulmin (2003) argüman modelinin beş bileşenini de içeren argümanlar daha nitelikli argüman olarak kabul edilmiştir. Ayrıca Toulmin argüman modelinin beş bileşenini de içeren kategoriler için $f>20$ (katılımc1 sayısısnın 2/3'ü) kriter olarak alınmıştır. Buna göre öğrencilerin her bir düşünce deneyini argüman olarak yeniden yapılandırırken her bir etkinlik için Toulmin 
argüman modelinin beş bileşenini de kullanma frekansları f: 32, 30, 31, 30, 32, 32, 31, 33, 31, 32, 33, 33 şeklindedir.

Buradan öğrencilerin daha öncesinde argüman yapılandırma becerilerini geliştirmeye yönelik bir öğrenim görmedikleri de dayanak noktası alınarak düşünce deneylerinin kullanıldığı argümantasyon temelli kimya öğretimi sürecinde öğrencilerin argümanlarının kalitesinin geliştirilmesi suretiyle argüman yapılandırma becerilerinin geliştirildiği söylenebilir. Tablo 4 'te sunulan bulguların güçlendirilmesi amacıyla öğrenci çalışma yapraklarından alıntılar aşağıda sunulmuştur:

Düşünce Deneyi 1: Uzay Aracı (Öğretim Programı Kazanım No: 9.3.5.1) Yeni bir gezegen keşfedildiğini ve bu gezegene de dünyadan keşif amaçlı bir uzay aracının gönderildiğini varsayınız. Gezegenin atmosferinin hidroklorik asit buharı içermesinden dolayı uzay aracının yalıtıcı seramikle, silisle kaplı dış yüzeyi aşınıyor. a.Uzay aracının dış yüzeyinin aşınmaması için silis nasıl korunabilir? b.Gezegenin atmosferi hidroklorik asit içerdiğine göre yer küresinin bileşimini yorumlayınız.

Ö33 kodlu ögrrencinin argümanı: Silis ve asit tepkimeye girmiştir (iddia). Uzay aracının dışı aşınmıştır (veri). $\mathrm{SiO}_{2(k)}+4 \mathrm{HCl}_{(g)} \rightarrow \mathrm{SiCl}_{4(k)}+2 \mathrm{H}_{2} \mathrm{O}_{(g)}$ (gerekçe). Gezegenin yer küresi aşınmadı̆̆ına göre asit gezegenin yer küresindeki kimyasallarla tepkimeye girmez (karşı destek). Silise altın katılırsa uzay aracının dışı asitle tepkimeye girmez (kendi iddasına karşı iddia) (çürütme).

Düşünce Deneyi 2: Yanan Gezegen (Öğretim Programı Kazanım No: 9.3.5.1) Uzayın bir yerlerinde yer küresinin büyük bir kısmı karbondan oluşan, atmosferinin büyük bir kısmı da oksijen olan bir gezegen olduğunu varsayınız. Ayrıca gezegenin ekliptik olarak döndüğü, gezegenin enerji kaynağının sıcaklığının gezegendeki karbon yer kürenin yanması için gerekli aktivasyon enerjisini sağlayamayacak kadar düşük olduğunu varsayınız. Uzayın bir yerlerinde gezegene yakın bir patlama olur ve gezegen yanmaya başlar. Yanma tepkimesini resmediniz.

Ö2 kodlu öğrencinin argümanı: Gezegende karbon - oksijen tepkimeye girmiştir (iddia). Gezegenin yanında patlama olmuş, ısı açı̆̆a çıkmıştır (veri). Patlama sonucu açı̆̆a çıkan ısıyla karbon ve oksijen yanmıştır; yanmanın başlaması için gerekli aktivasyon enerjisi sağlanmıştır (gerekçe). $\mathrm{C}_{(k)}+\mathrm{O}_{2(g)} \rightarrow \mathrm{CO}_{2(g)}+\imath$ si. ve esnek çarpışmazlarsa tepkimeye girmezler (çürütme).

Düşünce Deneyi 3: İlginç Canlılar (Öğretim Programı Kazanım No: 9.4.1.1) Uzayın bir yerlerinde bir gezegende okyanusların dünyadakinden farkı bir sıvıdan oluştuğunu ve bu okyanuslarda yaşayan canlı türlerinin olduğunu varsayınız. Gezegende ani ve aşırı sıcaklık değişimlerinin olması, okyanusları oluşturan sıvının katı ve sıvı hal arası bir forma dönüşmesine sebep olmaktadır. Okyanusları oluşturan sıvının katı ve sıvı hal arası bir forma dönüşmesini takiben okyanuslarda yaşayan canlı türleri de renk değiştirmektedir. Bu durumun sebebi ne olabilir?

Ö18 kodlu öğrencinin argümanı: Canlıda tepkime olmuştur (iddia). Canlıda renk değişimi olmuştur (veri). Sicaklık ve renk değişimi dayanak alınarak canlıda koordinasyon bileşiği oluşmuş olabilir (gerekçe). Tanecikler arası mesafe azalmıştır (destek). Renk değişimine sebebiyet verecek bir bileşik oluşmamış olabilir (çürütme).

Düşünce Deneyi 4: Tatlı Su Salyangozu (Öğretim Programı Kazanım No: 9.4.4.2) Ege Bölgesi'nde bir derede $3 \mathrm{~mm}$ boyunda yeni bir tatlı su salyangoz türünün bulunduğunu varsayınız. Bu salyangoz türünün derisinin elastikliğinin yüksek olduğunu ve atık kofullarındaki gaz miktarının da çok fazla olduğunu varsayınız. 
Dere sıcaklığından daha yüksek sıcaklıktaki laboratuvar ortamında salyangoz türü incelenirken, salyangoza ne olmasinı beklersiniz?

Ö3 kodlu öğrencinin argümanı: Salyangozun hacmi büyür (iddia). Laboratuvarın sıcaklı̆̆ının daha yüksek olması (veri). Daha sıcak ortamda salyangozun gaz tanecikleri daha hareketlenir, salyangozun hacmi artar (gerekçe). Peteğin üstüne konulan balonda da aynısı olur (destek). Laboratuvara götürmezsek bunların hiçbiri olmaz (çürütme).

Düşünce Deneyi 5: Kapsül (Öğretim Programı Kazanım No: 9.4.4.1)

Astronotların yaşamın olmadığı bir gezegende daha rahat araştırma yapmalarını sağlamak için bu gezegenin atmosferinin bileşimini değiştirmesi gerektiğini varsayınız. Gezegenin $\mathrm{CO}_{2}$ gazından oluşan atmosferine girdiği an kendini imha edecek ve içindeki gazları salacak kapsüller geliştirilmiştir. Kapsüller yalıtılmış ve içindeki gazların sıcaklık ve basıncı gezegene uyumlu olarak ayarlanmıştır. Kapsüllerin birinin içine aynı mol sayıda $\mathrm{O}_{2}$ gazı diğerinin içine $\mathrm{N}_{2}$ gazı konulmuştur. Kapsüllerin aynı anda atmosferden girişi sağlanırsa hangi gazın, gezegenin atmosferindeki difüzyon hızı daha iyidir? $\left(\mathrm{O}_{2}: 32, \mathrm{~N}_{2}: 28 \mathrm{~g} / \mathrm{mol}\right)$

Ö10 kodlu öğrencinin argümanı: Azot gazının difüzyon hızı oksijen gazından daha büyüktür (iddia). $\mathrm{O}_{2}: 32, \mathrm{~N}_{2}: 28 \mathrm{~g} / \mathrm{mol}$. Molekül kütlelerine baktık (veri). Molekül kütlesi küçük olanın difüzyon hızı daha büyüktür (gerekçe). Zayıf adam hızh koşar benzetmesinde olduğu gibi (destek). Böyle bir gezegen olmasaydı (düşünce deneyinin varsayımına dair sunulan zayıf çürütme).

Düşünce Deneyi 6: Sülfür Bakterileri (Öğretim Programı Kazanım No: 9.4.1.1) Bir yerleşim birimine yakın mesafedeki bir bataklıkta sülfür bakterilerinin ürettiğinden üç kat daha fazla metan gazı üreten mutasyona uğramış yeni sülfür bakteri türlerinin bulunduğunu varsayınız. Mutasyona uğrayan bu bakteri türü yerleşim biriminde zehirlenmelerin başlamasının ardından keşfedilmiştir. Metan gazının oksijenli solunum yapan canlılar için atmosfer kirletici olarak davrandığını göz önüne alarak; metan gazının, atmosferdeki gaz karışımındaki yüzdesini nasıl azaltırsinız?

Ö15 kodlu öğrencinin argümanı: Sülfür bakterisini azaltan bakteri üretmeliyiz (iddia). Sülfür bakterisinin normalin üç misli metan gazını atmosfere salması (veri). Aşırı metan gazı üreten bakterileri azaltmanın gerekliliği (zayıf gerekçe). Yeşil alan yapmadık çünkü metan gazı bitkileri de öldürür (destek). Sülfür bakterilerini azaltan yeni bakteri üretemezsek (çürütme).

Düşünce Deneyi 7: Yanardağ (Öğretim Programı Kazanım No: 9.4.1.1, 9.4.3.1, 9.4.3.2) Uzayda bir gezegende benzer boyutlarda, uyuyan ve faal, iki yanardağ keşfedildiğini varsayınız. Basınç ve sıcaklığın her iki yanardağın iç tabakalarında bulunan erimiş kayaları aynı etkilediğini ancak erimiş kaya türlerinin farklı olduğunu varsayınız. Yanardağların uyuyan ve faal olma sebebi ne olabilir?

Ö1 kodlu öğrencinin argümanı: Sebep kapilar etkidir (iddia). Yanardă̆ların biri uyuyor, biri faaldir (veri). Faal yanardă̆ın kapilarlı̆̆ı daha iyidir (gerekçe). Daha kapilar olanın adhezyonu kuvvetlidir (destek). Yanardağlar olmasaydı (düşünce deneyinin varsayımına dair sunulan zayıf çürütme).

Düşünce Deneyi 8: İki Gezegen (Öğretim Programı Kazanım No: 9.4.3.2)

Uzayda bir yerlerde enerji kaynağı bir yıldız ve bu yıldızın çekim etkisi altında kalan, bir yakın yörüngede bir de uzak yörüngede benzer özelliklerde iki gezegenin olduğunu varsayınız. Bu gezegenlerdeki aynı sıvıların viskozitelerini karşılaştırınız.

Ö13 kodlu öğrencinin argümanı: Güneşe yakın gezegenin sıvısı daha az viskozdur, yani daha akıcıdır (iddia). Birinci yörüngedeki gezegen güneşe daha yakındır (veri). Güneşe yakın olan 
gezegenin sıcaklığı fazla olduğundan sıvısının viskozluğu azdır (gerekçe). Güneşe uzak olan gezegenin sivısı daha viskozdur (destek). Viskozluk diye bir kavram olmasaydı (kavram geçerliği çürütme). Yıldız soğuk olsaydı (düşünce deneyinin varsayımına dair sunulan zayıf çürütme).

Düşünce Deneyi 9: Yeni Canlı Türü (Öğretim Programı Kazanım No: 9.4.3.3) Zonguldak'ta bir su kaynağında yeni bir canlı türünün bulunduğunu varsayınız. Bu canlı türünün incelenmek üzere yarıya kadar su doldurulmuş kapalı bir kaba yerleştirildiğini ve canlının da oksijenli solunum yaptığını; mol olarak harcadığı oksijen kadar karbon-dioksit ürettiğini varsayınız. Bir t süresi sonunda kabın denge buhar basıncı nasıl değişir?

Ö4 kodlu öğrencinin argümanı: Kaptaki suyun denge buhar basıncı değişmez (iddia). Su buharının yapmış olduğu çarpışmalar değişmez (veri). Su buharının yapmış olduğu çarpışmalar aynı olduğundan denge buhar basıncı da aynıdır (gerekçe). Sıcaklık aynıdır. Canlı molce ne kadar oksijen harcadıysa o kadar karbondioksit vermiştir (destek). Denge buhar basıncl olmasaydı (kavram geçerliği çürütme).

Düşünce Deneyi 10: Yeni Gezegen (Öğretim Programı Kazanım No: 9.4.3.4) Yeni bir gezegen bulunduğunu, gezegenin özelliklerinin dünyaya benzediğini ancak gezegenin su miktarının dünyadan çok fazla olduğunu varsayınız. Bu gezegen, güneşten daha güçlü bir enerji kaynağı olan bir yıldızın çekim etkisindedir ve bu yıldızın etrafında eliptik bir yörüngede ve dünya hesabıyla 200 günde dönmektedir. Kendi etrafında da dönen ve bu dönmeyi dünya hesabıyla 10 saatte tamamlayan bu gezegenin yıldızın etrafında dönerken 50. ve 100. günlerde atmosferindeki bağıl nem miktarlarını karşılaştırınız.

Ö2 kodlu öğrencinin argümanı: Gezegen yıldıza daha yakın olduğu zaman bă̆ıl nemi daha yüksektir (iddia). Yıldıza daha yakın olunca gezegenin hava sıcakliğı daha fazladır (veri). Hava sıcaklığı fazlaysa mutlak nem fazla, dolayısıyla bağıl nem fazladır (gerekçe). Gezegen yıldızdan uzaklaşınca bağıl nem düşer (destek). Gezegen olmasaydı (düşünce deneyinin varsayımına dair sunulan zayıf çürütme). Yıldız olmasaydı (düşünce deneyinin varsayımına dair sunulan zayıf çürütme).

Düşünce Deneyi 11: Gezegen Halkası (Öğretim Programı Kazanım No: 9.4.4.3) Bir gezegenin etrafındaki atık parçalar gezegenin dönme ve çekim gücüyle, gezegenin etrafında halka şeklinde bir katman oluşturur. Bu parçaları dağılmadan gezegenin etrafında tutan en önemli unsur da buzdur. Bir halkalı gezegene yakın mesafede bir evren parçasında bir patlama olduğunu ve bu patlama sonuncu 1sı açı̆̆a çıktığını, bu ısının da gezegen halkasındaki parçaları bir arada tutan buzu erittiğini varsayınız. $\mathrm{H}_{2} \mathrm{O}^{\prime}$ nun hal değişimi grafiğine paralel olarak gezegen halkası miktarını yorumlayınız.

Ö28 kodlu öğrencinin argümanı: Gezegen halkası azalır (iddia). Patlama sonucu ısı açı̆̆a çıkmıştır (veri). Isı açı̆̆a çıkınca buz erir, gezegen halkası taneciklerini de buz birarada tuttuğu için gezegen halkası da azalır (gerekçe). Hal değişim grafiğinde buz kütlesi azalır (sıcaklıkzaman-madde miktarı üç boyutlu hal değişim grafiği kullanıldığında) (destek). Patlama olmasaydı (düşünce deneyinin varsayımına dair sunulan zayıf çürütme).

Düşünce Deneyi 12: Radyoaktif Gezegen (Öğretim Programı Kazanım No: 9.4.2.1) Radyoaktifliği düşük elementleri barındıran bir gezegenin keşfedildiğini varsayınız. Bilim insanlarınca keşif amaçlı gönderilen uzay aracının dış yüzeyi yalıtıcı seramikle kaplanırken silisin içerisine zeolit presleme de yapılmıştır. Zeolitin düşük düzeyde radyoaktif element soğurma özelliğinde kristal yapısının fonksiyonu nedir? 
Ö21 kodlu öğrencinin argümanı: Zeolit kristal yapısından dolayı radyoaktif element soğurur (iddia). Radyoaktif gezegene gönderilen uzay aracının dışı zeolit preslenmiştir (veri). Uzay aracının dışına zeolit presleme yapılmış ki kristal yapısından dolayı radyoaktif tanecik soğursun (gerekçe). Çünkü zeolitin kristal yapısı gözenekli ve iyon değiş̧tirme özelliğine sahiptir (destek). Zeolit diye bir madde olmasaydı (kavram geçerliği çürütme). Zeolit kristal değil, amorf olsaydı (kavram geçerliği çürütme). Böyle bir gezegen olmasaydı (düşünce deneyinin varsayımına dair sunulan zayıf çürütme).

\section{Tartışma, Sonuç ve Öneriler}

Bu çalışmada kimya eğitiminde düşünce deneylerinin kullanıldığı argümantasyon temelli öğretimle lise öğrencilerinin argümantasyonlarının ve argümanlarının kalitesinin geliştirilmesi suretiyle eleştirel düşünme becerileri geliştirilmiştir.

Öğrencilerin argümantasyonlarının kalitesi sosyal diyalektik argümantasyonla geliştirilmiştir. Öğrenciler sosyal diyalektik argümantasyon sürecinde birbirlerinin düşünme stratejilerini takip edebilmişlerdir. Çünkü birbirlerinin iddialarına karşı iddia ve çürütmeler sunabilmişlerdir. Bu sonuç, Tümay ve Köseoğlu'nun (2011) “Kimya öğretiminde bilimsel tartışmaların gerçekleştiği sınıflarda yetişen öğrenci bir meselede karar verirken açık fikirli, kuşkucu ve sorgulayıcı bir tutumla alternatif açıklamalar üzerinde düşünebilir; tartışmalarda öne sürülen iddiaları ve gerekçeleri kritik ederek bilinçli karar verebilir," ifadesiyle desteklenmektedir.

“Fen eğitiminde argümantasyon öğrenimi ve öğretiminde yetersiziz. Öyle ki fen müfredatı okumuş bireyler bile günlük yaşama dair iddialarını savunma ve iddialarına delil sağlamada yetersiz kalmaktadırlar" (Erduran, Ardac ve YakmaciGuzel, 2006). İddialara delil sağlama, etkili karar vermeyi tartışma becerisini de geliştirme için gereklidir (Maloney ve Simon, 2006). Bu çalışmada da öğrencilerin sosyal diyalektik argümantasyon bağlamında iddialarına deliller sağlamayı deneyimlemelerine ve birbirlerinin argümanlarını takip etmek suretiyle alternatifler arasından en makul olana dair etkili karar vermeyi tartışmalarına olanak verilmiştir. Böylece, öğrencilerin günlük yaşamlarına dair iddilarını savunma ve iddialarına delil sağlamada onlara ön-yaşanmışlıklar edindirilmiştir.

Öte yandan Walton'a (2006) göre bir argümantasyon sürecinde öğrenciler sadece kendi iddialarını ve gerekçelerini göz önünde bulundurmamalıdırlar; kendi argümanlarına karşı-argümanları da göz önünde bulundurmalıdırlar. Böylece argümantasyon süreci daha güçlü olacaktır. Benzer olarak bu çalışmadaki sosyal diyalektik argümantasyon sürecinde de hem öğrenciler kendi argümanlarını, hem diğerlerinin argümanlarını hem de kendi argümanlarına karşı-argümanları göz önüne almışlardır. Bu sayede argümantasyon kalitesinde sadece seviye 2 (iddia + veri/gerekçe/destek) argümanları edinilmemiş; çürütme durumları içeren seviye 4 argümanlarının frekansı da yüksek bulunmuştur.

Öğrencilerin argümanlarının kalitesi ise zihinsel diyalektik argümantasyonla geliştirilmiştir. Öğrenciler düşünce deneylerini argüman olarak yeniden kurgularken bir yandan da kendilerinin düşünme stratejilerini takip edebilmişlerdir. Çünkü iddialarına veriler, gerekçeler ve destekler sunabilmişlerdir. Böylece öğrenciler Erduran ve Pabuccu'nun (2012) da araştırmalarında belirttikleri gibi sonucu ifade etme, delil değerlendirme, savunulana destek sağlama yani argüman yapılandırma öğrenme süreçlerini deneyimlemişlerdir. 
Öğrencilerin sosyal diyalektik argümantasyon sürecinde "sonucu desteklemek için nedenler yapılandırma becerileri" ile "karşı-argümanlar yapılandırma becerileri", düşünce deneyleri yapılandırma sürecinde "muhakeme gerektiren durumlar yapılandırma becerileri", düşünce deneyini argüman temelinde ifade etme sürecinde de "argüman yapılandırma becerileri" geliştirilmiştir. Cambridge Düşünme Becerileri Müfredatında (2020-2022) eleştirel düşünme becerisi kategorisinde tanımlanan bu becerilerin geliştirildiği takdirde öğrencilerin eleştirel düşünme becerilerinin de gelişeceği vurgulanmaktadır. Buradan kimya eğitiminde düşünce deneyleri ile öğrencilerin argümantasyon becerilerinin geliştirilmesi suretiyle eleştirel düşünmelerinin de geliştirildiği söylenebilir. Bu durum alanyazından Vieira, Tenreiro-Vieira, ve Martins'in (2011) "Eleştirel düşünmenin fen müfredatlarına entegre edilmesi; öğrencilerin kendilerinin düşünme süreçlerinin ve diğerlerinin düşünme stratejilerinin farkına varmasını ve eleştirel düşünme becerilerinin geliştirilmesini sağlar." ifadesiyle de desteklenebilir.

Öte yandan argümantasyon odaklı kimya öğretiminde amaç öğrencilerin bildikleriyle ne yaptıkların belirlemek ve de onların bildiklerini bizim de bilmemiz amacıyla etkinlikler yürütmektir. Öyle ki yaygın olan öğretmenlerin öğrenci başarısını değerlendirirken; sonuca puan verme eğilimleridir (Erduran ve Yan, 2009). Alanyazına paralel olarak bu çalışmada düşünce deneyleri kullanılarak argümantasyon temelinde kimya öğretimi süresince yürütülen etkinliklerle; öğrencilerin yeni öğrendikleri bilgiyi ölçüp puanlamak yerine sosyal diyalektik argümantasyona katılma, düşünce deneylerinden düşünce deneyleri üretme ve düşünce deneylerini argüman olarak yapılandırma sayesinde bilgiyi kullanmaları sağlanmıştır.

Bütün bunlar göz önüne alındığında bu çalışma için bulunan sonuçlar şöyledir:

1.Düşünce deneylerinin kullanıldığı argümantasyon temelli kimya öğretimiyle sosyal diyalektik argümantasyonla öğrencilerin argümantasyon kalitesi geliştirilmiştir.

2.Düşünce deneylerinin kullanıldığı argümantasyon temelli kimya öğretimiyle zihinsel diyalektik argümantasyonla öğrencilerin argüman kalitesi geliştirilmiştir.

3. Öğrencilerin sosyal diyalektik argümantasyon sürecinde "sonucu desteklemek için nedenler yapılandırma becerileri" ile "karşı-argümanlar yapılandırma becerileri", düşünce deneyleri yapılandırma sürecinde "muhakeme gerektiren durumlar yapılandırma becerileri", düşünce deneyini argüman temelinde ifade etme sürecinde de "argüman yapılandırma becerileri" geliştirilmiştir.

4. Bu çalışmada uygulanan düşünce deneylerinin kullanıldığı argümantasyon temelli kimya öğretimi uygulama sürecinde, lise öğrencilerinin argümantasyonlarının ve argümanlarının kalitesini geliştirmek suretiyle onların eleştirel düşünme becerilerinin geliştiği sonucuna varılmıştır.

Lisede fen sınıflarında öğrenciler bilimsel tartışma imkânı çok fazla bulamamaktadırlar (Lemke, 1990). Argümantasyonun fen sınıflarındaki kullanımını artırmak için; fen eğitiminde düşünce deneylerinin kullanıldığı argümantasyon temelli öğretimle lise öğrencilerinin argümantasyonlarının ve argümanlarının kalitesinin geliştirilmesi suretiyle eleştirel düşünmelerinin geliştirilmesi amacıyla bu 
araştırmanın ileriki çalışmalara 1şık tutması beklenilmektedir. Araştırmanın uygulama sürecinin çok aşamalı olması ve bütün araştırmanın detaylı betimlenmesi ile bu araştırmayı kendilerine rehber alacak eğitimcilerin ve araştırmacıların araştırmadaki özgün düşünce deneylerini kendi öğretim ortamlarında kullanabilmeleri; çalışma bağlamını kendi öğretim ortamlarına uyarlayabilmeleri ve de sosyal diyalektik bir argümantasyon sürecinin ya da öğrenci argümanlarının nasıl çözümlenebileceği hususunda temel alabilecekleri örnek bir çalışmanın olması sağlanmaya çalışılmıştır.

\section{Kaynakça}

Bademci, S. (2008). Fizik problemleri çözmede düşünce deneylerinin yeri: Birinci ve beşinci sinıf fizik ögrretmen adaylar üzerine bir inceleme. Yüksek Lisans Tezi, Gazi Üniversitesi Eğitim Bilimleri Enstitüsü, Ankara.

Bailin, S. (2002). Critical thinking and science education. Science and Education, 11, 361-375. https:/ / doi.org/10.1023/A:1016042608621

Cambridge International AS and A Level Thinking Skills 9694, Syllabus (2020-2022), https://www.cambridgeinternational.org/Images/415052-2020-2022syllabus.pdf.

Cooper, R. (2005). Thought experiments. Metaphilosophy, 36(3), 328-347. https:// doi.org/10.1111/j.1467-9973.2005.00372.x

Dayı, B. (2011). Kaldırma kuvveti ve basınç konusundaki problemlerin çözümünde düşünce deneylerinin yeri. Yüksek Lisans Tezi, Gazi Üniversitesi Eğitim Bilimleri Enstitüsü, Ankara.

Driver, R., Newton, P., and Osborne, J. (2000). Establishing the norms of scientific argumentation in classrooms. Science Education, 84, 287-312. https:// doi.org/10.1002/(SICI)1098-237X(200005)84:3<287::AIDSCE1>3.0.CO;2-A

Erdoğan, M. N., Özbilgin, F., ve Köseoğlu, F. (2007, Haziran). Elementlerin periyodik sisteminin lise öğrencilerine bilimsel tartışma stratejileri kullanılarak yap - boz sinıf ortamında öğretim ile ilgili uygulamalar ve çıkarımlar. I. Ulusal Kimya Eğitimi Kongresi'nde sunulmuş bildiri, Nişantaşı Nuri Akın Anadolu Lisesi, İstanbul.

Erduran, S. (2006). Promoting ideas, evidence and argument in initial science teaching training. School Science Review, 87(321), 45-50.

Erduran, S., Ardac, D., and Yakmaci-Güzel B. (2006). Learning to teach argumentation: Case studies of pre-service secondary science teachers. Eurasia Journal of Mathematics, Science and Technology Education, 2(2), 1-14. https:// doi.org/10.12973/ ejmste/ 75442

Erduran, S., Guilfoyle, L., Park, W., Chan, J., and Fancourt, N. (2019). Argumentation and interdisciplinarity: reflection from the Oxford argumentation in religion and science project. Disciplinary and Interdisciplinary Science Education Research, 1(8), 1-10. https:/ / doi.org/10.1186/s43031-019-0006-9

Erduran, S., Kaya, E., and Çetin, P. S. (2016). Pre-service teachers' perceptions of argumentation: Impact of a teacher education project in Rwanda. Boğaziçi Üniversitesi Eğitim Dergisi, 33(1), 5-25.

Erduran, S., and Msimanga, A. (2014). Science curriculum reform in South Africa: Lessons for professional development from research on argumentation in 
science education. Education as Change, 18(S1), S33-S46.

https:// doi.org/10.1080/16823206.2014.882266

Erduran, S., and Pabuccu, A. (2012). Bonding chemistry and argument: Teaching and learning argumentation through chemistry stories, https:/ / limerick.academia.edu/SibelErduran.

Erduran, S., Simon, S., and Osborne, J. (2004). TAPping into argumentation:

Developments in the application of Toulmin's argument pattern for studying science discourse. Science Education, 88, 915-933.

https://doi.org/10.1002/sce.20012

Erduran, S., and Yan, X. (2009). Minding gaps in Argument: Continuing professional development to support the teaching of scientific inquiry,

https:/ / limerick.academia.edu/SibelErduran.

https:// doi.org/10.12968/nuwa.2009.6.1.1092203

Eyceyurt-Türk, G., Tüysüz, M., ve Tüzün, Ü. N. (2018). Organik kimya kavramlarının öğretiminde düşünce deneyleri temelli argümantasyonun lise öğrencilerinin eleştirel düşünme becerilerine etkisi. Kastamonu Eğitim Dergisi, 26(6), 20212032. https:// doi.org/10.24106/kefdergi.2305

Foton Tartısı. http:/ / www.abecem.net/bilim/foton-tartisi.htm.

Gendler, T. (1998). Galileo and the indispensability of scientific thought experiment. British Journal for the Philosophy of Science, 49, 397-424. https:// doi.org/10.1093/bjps/49.3.397

Georgiou, A. (2005). Thought experiments in physics problem-solving: On intuition and imagistic simulation. MS Thesis, University of Cambridge, Cambridge.

Gilbert, J., and Reiner, M. (2000). Thought experiments in science education: Potential and current realization. International Journal of Science Education, 22(3), 265283. https:/ / doi.org/10.1080/095006900289877

Hefter, M. H., Berthold, K., Renkl, A., Riess, W., Schmid, S., and Fries, S. (2014). Effects of a training intervention to foster argumentation skills while processing conflicting scientific positions. Instructional Science, 42, 929-947. https: / / doi.org/10.1007/s11251-014-9320-y

Ireson, G. (2005). Einstein and the nature of thought experiments. School Science Review, 86(317), 47-51.

Köseoğlu, F., Tümay, H., ve Akben, N. (2007, Haziran). Argümantasyona dayalı öğretim uygulamalarm öğrencilerin asitlik/bazlik kuvveti, derişim ve $p H$ konusundaki kavramsal değişimlerine ve kimyaya karşı tutumlarına etkisi. I. Ulusal Kimya Eğitimi Kongresi'nde sunulmuş bildiri, Nişantaşı Nuri Akın Anadolu Lisesi, İstanbul.

Lattery, M. J. (2001). Thought experiments in physics education: A simple and practical example. Science and Education, 9, 1-13.

Lazarou, D., Erduran, S., and Sutherland, R. (2017). Argumentation in science education as an evolving concept: Following the object of activity. Learning Culture and Social Interaction, 14, 51-66. https:// doi.org/10.1016/j.lcsi.2017.05.003

Lemke, J. L. (1990). Talking science: Language, learning and values. Norwood, NJ: Ablex. Maloney, J., and Simon, S. (2006). Mapping children's discussions of evidence in science to assess collaboration and argumentation. International Journal of 
Science Education, 28(15), 1817-1841.

https:// doi.org/10.1080/09500690600855419

Mamlok-Naaman, R., Ben - Zvi, R., Hofstein, A., Menis, J., and Erduran, S. (2005).

Learning science through a historical approach: Does it affect the attitudes of none - science - oriented students towards science? International Journal of Science and Mathematics Education, 3(3), 485-507. https: / / doi.org/10.1007/s10763-005-0696-7

Norton, J. (1991). Thought experiments in Einstein's work. Thought experiments in science and philosophy. T. Horowitz and G. J. Massey (Eds), 129-144. Maryland: Rowman \& Littlefield Publishers.

Norton, L. S. (2009). Action research in teaching and learning. London and New York: Taylor and Francis. https:/ / doi.org/10.4324/9780203870433

Nussbaum, E. M., and Edwards, O. V. (2011). Critical questions and argument stratagems: A framework for enhancing and analyzing students' reasoning practices. The Journal of the Learning Sciences, 1-46. https:/ / doi.org/10.1080/10508406.2011.564567

Ortaöğretim Kimya Dersi Öğretim Programı (2018), http:/ /ttkb.meb.gov.tr.

Osborne, J., Erduran, S., and Simon, S. (2004). Enhancing the quality of argumentation in school science. Journal of Research in Science Teaching, 41(10), 994-1020. https:/ / doi.org/10.1002/tea.20035

Osborne, J., Erduran, S., Simon, S., and Monk, M. (2001). Enhancing the quality of argument in school science. School Science Review, 83(301), 63-70.

Özer, G. (2009). Bilimsel tartışmaya dayalı öğretim yaklaşımının öğrencilerin mol kavramı konusundaki kavramsal değişimlerine ve başarılarına etkisinin incelenmesi. Yüksek Lisans Tezi, Gazi Üniversitesi Eğitim Bilimleri Enstitüsü, Ankara.

Pabuccu, A., and Erduran, S. (2017). Beyond rote learning in organic chemistry: The infusion and impact of argumentation in tertiary education. International Journal of Science Education, 39(9), 1154-1172. https:// doi.org/10.1080/09500693.2017.1319988

Reiner, M. (1998). Thought experiments and collaborative learning in physics. International Journal of Science Education, 20(9), 1043-1058. https:/ / doi.org/10.1080/0950069980200903

Rescher, N. (1991). Thought experimentation in Pre-Socratic philosophy. T. Horowitz and G. J. Massey (Eds.), Thought experiments in science and philosophy, (pp. 3141). Maryland: Rowman \& Littlefield.

Sagor, R. (2000). Chapter 1: What is action research? Action research. http:/ / www.ascd.org/publications/books/100047/chapters/What-IsAction-Research\%C2\% A2.aspx.

Simon, S., Erduran, S., and Osborne, J. (2006). Learning to teach argumentation: Research and development in science classroom. International Journal of Science Education, 28, 235-260. https:/ / doi.org/10.1080/09500690500336957

Tekeli, A. (2009). Argümantasyon odaklı sınıf ortamının öğrencilerin asit - baz konusundaki kavramsal değişimlerine ve bilimin doğasını kavramalarına etkisi. Yüksek Lisans Tezi, Gazi Üniversitesi Eğitim Bilimleri Enstitüsü, Ankara.

Toulmin, S. (2003). The uses of argument. New York USA: Cambridge University. https://doi.org/10.1017/CBO9780511840005 
Tümay, H., ve Köseoğlu, F. (2011). Kimya öğretmen adaylarının argümantasyon odaklı öğretim konusunda anlayışlarının geliştirilmesi. Türk Fen Eğitimi Dergisi, 8(3), 105-119.

Türk, G. E., and Kılıç, Z. (2020). The effect of argumentation-supported problem based learning on the achievements of science teacher candidates regarding the subjects of gases and acids-bases. Bartın Üniversitesi Ĕ̆itim Fakültesi Dergisi, 9(2), 440-463. https:/ / doi.org/ 10.14686/buefad.643630

Tüzün, Ü. N., ve Köseoğlu, F. (2018). Bilim eğitiminde düşünce deneyleri temelli online argümantasyonla lise öğrencilerinin eleştirel düşünme becerilerinin geliştirilmesi. Türkiye Kimya Derneği Dergisi Kısım C: Kimya Eğitimi, 3(2), 7798.

Vieira, R. M., Tenreiro-Vieira, C., and Martins, I. P. (2011). Critical thinking: Conceptual clarification and its importance in science education. Science Education International, 22(1), 43-54.

Walton, D. (2006). Fundamentals of critical argumentation. New York USA: Cambridge University. https:/ / doi.org/10.1007/s10503-006-9013-z

West, T. L. (1994). The effect of argumentation instruction on critical thinking skills. Doctoral Dissertation, Southern Illinois University, Chicago.

Yıldırım, A., ve Şimşek, H. (2008). Sosyal bilimlerde nitel araştırma yöntemleri. Ankara: Seçkin.

\section{Summary}

\section{Problem Statement}

\section{Introduction}

Every individual makes decisions for daily life. An individual could make plausible decisions only if he/she thinks critically. Critical thinking means plausible and reflective thinking for deciding what to believe or what to do (Norris ve Ennis, 1989, cf., West, 1994). Argumentation is a strategy for teaching critical thinking (West, 1994, p. iii). Argumentation means coordinating evidence and claim for judging the validity of the conclusion. Argument means claim, data and warrant whereas argumentation means combining these components (Erduran ve Msimanga, 2014; Erduran ve Yan, 2009; Simon, Erduran ve Osborne, 2006; Toulmin, 2003). Toulmin (2003) stated that an argument consisted of claim, data, warrants, backings, limiters and rebuttals. A thought experiment could be reconstructed as an argument (Ireson, 2005). A thought experiment means to conclude what would happen if a particular scenario comes true (Gendler, 1998). Reiner (1998) determined that a hypothetical world, a hypothesis, an experiment carried out in mind, conclusions based on previous experiences and logic, a decision based on these conclusions were the components of a thought experiment. When looked at the literature, it was found that studies integrating critical thinking argumentation - thought experiments were not so common. So the problem sentence of the study is "How could high school students' critical thinking skills be enhanced via enhancing their argumentation and argument skills with argumentation based chemistry teaching, in which thought experiments are utilized, in science education?" 


\section{Purpose of the Study}

The purpose of the present study is to enhance high school students' critical thinking skills via enhancing their argumentation and argument skills in a thought experiments and argumentation-based teaching domain in chemistry education.

\section{Method}

In the study, as one of the qualitative research designs, action research was used. The participants of the study were 33, ninth grade students being educated in a high school in Ankara province. In the application process, social dialectic argumentation for the argumentation of the thought experiments and for the reconstruction of alternative thought experiments was carried out. And also logical dialectic argumentation for reconstruction of the thought experiments as arguments was carried out as well. As data collecting tools, camera records and teaching sequence worksheets were utilized. The teaching sequence worksheets consisted of 12 thought experiments making students reconstruct the thought experiments as arguments on the basis of Toulmin's (2003) argument pattern components (claim, data, warrant, backing, rebuttal). The data collecting tools content validity was checked by three science educators including the researcher and reliability was guaranteed by the same science educators' coding and categorizing consistency. Content analysis was utilized for the whole gathered data.

\section{Results}

As the findings of the study, the students criticized each other's arguments in a social dialectic argumentation process. For debating the thought experiments, they constructed claims, data, warrant and backings. They constructed rebuttals against counter arguments. They also constructed rebuttals for determining when their warrants would be invalid. Besides, through the social dialectic argumentation process, the students constructed alternative thought experiments which means they could construct cases requiring judgments. For logical dialectic argumentation process, the students individually reconstructed each of the 12 thought experiments on the basis of Toulmin argument pattern components (claim, data, warrant, backing, and rebuttal). An example could be seen below.

Radioactive Planet Thought Experiment: Suppose a low-level radioactive planet was discovered. For sending a space robot to this planet, the scientists covered the space robot's silica surface zeolite pres. What is the crystal structure function of zeolite for absorbing the low radiation?

The argument of the student coded by S21: Because of the its crystal structure, zeolite absorbs radiation (claim). Zeolite press was made on the surface of the space robot which was shipped to this planet (data). Zeolite press was made on the surface of the space robot, so that because of zeolite's crystal structure, it could absorb radiation (warrant). Zeolite's crystal structure is cellular and has the characteristics of ion chancing (backing). If there was not a matter called zeolite (then there would not be any claims, warrants ...) (rebuttal for concept validity). If the zeolite was amorphous instead of crystal (then there would not be any claims, warrants ...)(rebuttal for concept validity). If there was no planet like this (then there would not be any claims, warrants ...)(rebuttal for thought experiment's assumption). 


\section{Discussion}

At the end of the research, it was found that high school students' critical thinking skills were enhanced via strengthening their argumentation and the quality of their arguments by means of argumentation-based chemistry teaching that employs thought experiments in science teaching. As Tümay and Köseoğlu (2011) stated the students could think critically on alternative explanations only if they experienced argumentation teaching domains.

\section{Pedagogical Implications}

For further studies it could be suggested to enhance high school students' critical thinking skills via enhancing their argumentation and argument skills in a thought experiments-based argumentation in different science education domains. Also the current study could be taken as a guide by educators and researchers for constructing their own teaching environments on the basis of thought experiments - argumentation - critical thinking triangulation by the help of the study's detailed application and data analysis processes.

\section{Teşekkür}

Makalenin yazım aşamasındaki katkılarından dolayı çok değerli Hocam Prof. Dr. Fitnat KÖSEOĞLU’na sonsuz teşekkürlerimi sunarım.

\section{Araştırmanın Etik Taahhüt Metni}

Yapılan bu çalışmada bilimsel, etik ve alıntı kurallarına uyulduğu; toplanan veriler üzerinde herhangi bir tahrifatın yapılmadığı, karşılaşılacak tüm etik ihlallerde "Cumhuriyet Uluslararası Eğitim Dergisi ve Editörünün" hiçbir sorumluluğunun olmadığ1, tüm sorumluluğun Sorumlu Yazara ait olduğu ve bu çalışmanın herhangi başka bir akademik yayın ortamına değerlendirme için gönderilmemiş olduğu sorumlu yazar tarafından taahhüt edilmiştir.

\section{Author's Biodata/ Yazar Bilgileri}

Ümmüye Nur TÜZÜN Kimya Öğretmenliğinde lisans, yüksek lisans ve doktora derecesine sahiptir. Adli Kimya-Adli Toksikoloji alanında ikinci doktora eğitimine devam etmektedir. 13 yıllık devlet öğretmeni olup son beş yıldır Ankara' daki bir Bilim ve Sanat Merkezinde özel yetenekli öğrencilerin öğretmenidir.

Ümmüye Nur Tüzün has taken Bachelors', MS and $\mathrm{PhD}$ degrees on Chemistry Education. She is still educating in Forensic Chemistry and Forensic Toxicology program for the second PhD degree. She has been a government teacher for 13 years and has been teaching special gifted students at a Science and Arts Center in Ankara for the last five years. 